\title{
セルラニューラルネットワークに よる連想記憶の医療診断への応用
}

\author{
章 忠 ${ }^{1)}$ 金川明弘 ${ }^{2)}$ 川畑洋昭 ${ }^{2)}$
}

\begin{abstract}
医療診断をコンピュータ上で実現するのはある種の困難が直面される．その理由は医療診断が数十以上の項 目(特徵量)からなるデータにより多数の病気群を総合的に判断寸る必要があるためである。本研究では優れた 連想能力を持つセルラニューラルネットワーク $(\mathrm{CNN})$ を用いて計算機支援医療診断システムを構成し, 肝臓病 を例にしてその判定能力を検討した，その結果，本研究で検討した条件において，CNNから良好な診断結果が 得られた。その理由として，CNN は人間に比較的近い連想能力を持つシステムが実現でき，病気パターンの全 体の特徵を㧽みやすく，専門家による総合判断に極めて近い判断ができるからだと考えられる。
\end{abstract} キーワード：ニューラルネットワーク，分類，診断，肝臓病

\section{1. はじめに}

医療診断において，臨床医は通常問診および血液検 查の結果から病気を判断する.問診および血液検査の 結果からだけでは判定ができない場合には，精密検査 を行いその結果から再び判断を行うこととなる．健康 診断や人間ドックなどのように大量のデータが発生す る場合，診断効率の向上に計算機支援医療診断システ ムの適用が期待されている。計算機支援医療診断は医 者に成り代わり，責任のある診断はしないが、警告を 出すところまでは到達すべきであると考えると, 病名 の特定まで視野に入れた正確な判定システムの構築が 大変重要である。

従来, 古典的な数理統計学の立場からは, 本問題は 多変量解析法の判別分析問題に属すると考えられる. 特に最近，「根拠に基づく医療」が盛んに議論され，医 療診断の問題に対する統計的接近の研究は盛んに行わ れている。しかしながら，判別分析法における多変量 正規分布の仮定や，多群になったときの判別関数の構 成の難しさなど実際問題への適用には課題が多い。ま た，多くのデータから判別システムを学習により自動 生成させる方法として，階層型ニューラルネットワー クが知られている $[1,2]$.この場合のニューラルネット ワークとはフィードフォワード型の信号伝播をし, 誤

1）岡山祡工業技術センターシステム技術部 テ701-1296 岡山市芳 賀5301番地（Tel.086-286-9620）

Industrial Technology Center of Okayama Prefecture, 5301 Haga, Okayama 701-1296, Japan

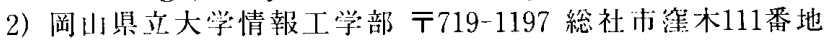
(Tel.0866-94-2092)

Okayama Prefectural University, 111 Kuboki Soja 719-1197, Japan
差逆伝播法(Error Back-Propagation)により教師デ一 夕との差の二乗和が最小になるようなシナプス結合を 持つニューラルネットワークシステムが最終的に得ら れる. 階層型ニューラルネットワークの判別分析など への適用は，ブラックボックス的接近とみなされ，デ 一夕からの知識獲得を目指した探索的データ解析と見 なしにくい部分がある $[3,4]$.

本研究で提案するのは，相互結合型のセルラニュー ラルネットワーク (Cellular Neural Network, CNN) を用い，学習によらず，既存の知識に基づいてニュー ラルネットワークの連想記憶能力による判定を行う判 別法である.CNN は図 1 に示すように, セルと呼ばれ る単純なアナログ回路をマトリクス状に配置し構成さ れるものである $[5,6,7]$. 各セルの状態は近傍 $r$ 範囲内 のセルの状態の影響を受けながら微分方程式系で変化 し, システムの漸近安定平衡点 (以下, 平衡点と呼ぶ) に収束する特性を持っている。この特性は自己想起機 能といえ, CNN を連想記憶媒体として判別問題に応用 する際に重要な役割を果なしている。例えば，各デー 夕群の特徵に基づいて作成された特徴パターン（記憶パ ターン)が CNN システムの平衡点に記憶させた(設定方 法は2.1節で詳しく紹介する)とする。あるサンプルか ら作成されたパターン(初期パターン)をCNNに入力し た後，各セルの状態は周囲セルの影響，すなわちパ夕 ーン全体の特徵を受けながら微分方程式系で変化し, ある平衡点に収束する。これに応じて, CNN は与えら れた初期パターンから平衡点にある記憶パターンを想 起し，その初期パターンが想起された記憶パターンの デー夕群に属することを判定する。このような CNN は 連想記憶に優れた能力を有するため, 現在多くの研究 者の関心が集められている[8].著者らの研究 $[9,10] に$ 
よれば, CNN はデー夕の項目 (特徴量)が多いほど連想 記憶能力が高く, 判定可能な群数 (記憶パ夕ーン数)が 項目数に比例して増加する．また，各七ルとその近傍 の結合状態を表すテンプレート行列には記憶パターン の情報も含んでいるため，分類問題に応用する際に入 力データと出力結果との因果関係の検討や誤認識の原 因究明などが容易である。そのため, CNNにより新た な計算機支援医療診断システムを構成することが期待 できる.

血液検査などの項目は“低一正常一高”や“正常一 過剩一大きい過剩”というような，3レベルで検查結 果を表すことが多い.例之ば, 血液中の $\gamma$-GTPは0〜50 $\mathrm{IU} / l$ が正常範囲であるが, 50 100 IU $/ l$ となると軽度 超過, $100 \mathrm{IU} / l$ 以上となると重度超過という病状が診 断される。すなわち, CNN を用いて検査結果から病気 を判定する際，“低一中一高”の 3 值に対応することが 要求されている.しかし, 従来の CNN の各セルの安定 状態は二種類 ( 2 值) しかない $[5,6]$. したがって，この ような“低一中一高”の 3 值に対応できる CNN，すな わち各セルが三つの安定状態を有するネットワークの 開発が当面の課題となる.

本研究ではまず 3 值出力関数の設計を提案しそれを 用いる 3 値の CNN (Three-valued Cellular Neural Network，T-CNN)を検討する。そして，T-CNNを 用いる診断システムを構成し, 肝臓病の診断を例にし て提案手法の有効性を明らかにする。

\section{3 值セルラニューラルネットワーク (T-CNN)の検討}

\subsection{2 值 CNN の吟味}

図 1 に示したCNN において, $i$ 行, $j$ 列のセルはそ のセルの近傍とのみ連結され，その影響を受けながら 次の微分方程式系で变化する $[5]$.

$$
\begin{gathered}
\dot{x}_{i j}=-x_{i j}+T_{i j} * y_{i j}+* S_{i j}+u_{i j}+I_{i j} \\
(1 \leqq i \leqq m, 1 \leqq j \leqq n)
\end{gathered}
$$

ここで $x_{i j}, u_{i j}$ は $(i, j)$ セルにおけるそれぞれ状態変数, 制御入力を表し， $I_{i j}$ は闌值をあらわしている. $T_{i j}, S_{i j}$ は $(i, j)$ セル近傍のセルからの出力及び入力の影響をあ らわすテンプレート行列である.出力関数 $y_{i j}=\operatorname{sat}\left(x_{i j}\right)$ は図 2 に示すような状態 $x_{i j}$ の区分線形関数であるため, 式（1）は各線形領域において線形微分方程式となる。た だし, 四中の $L$ は $y_{i j}$ の非飽和領域の大きさ, $s$ は非飽 和領域の起点である。

議論を簡単にするため, 制御入力を $u_{i j}=0$ とし, 式 (1)で与えられた $N=m \times n$ 個のセルの微分方程式を一 括してべクトルの形式で表現すると，

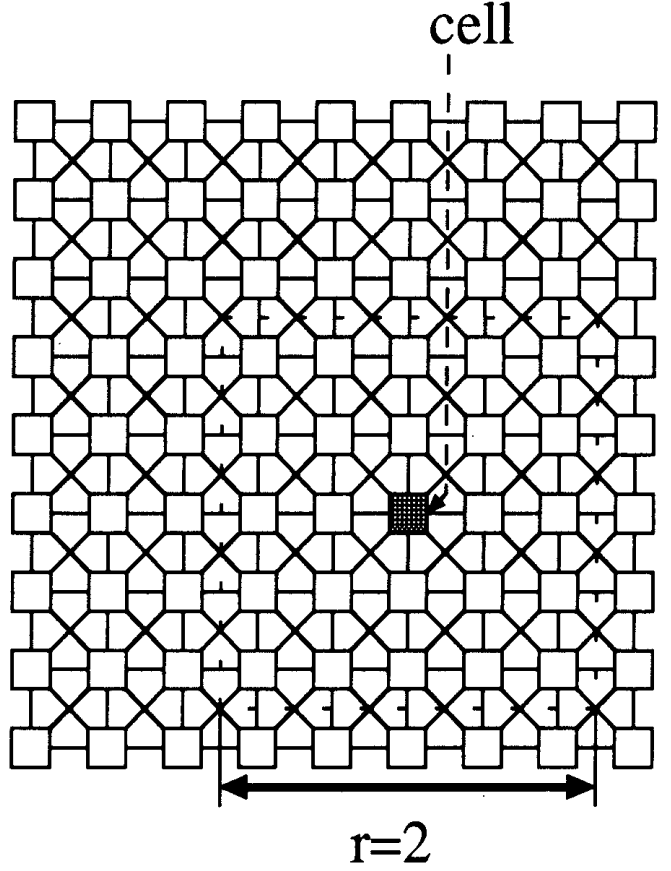

図1 $9 \times 9 \mathrm{CNN}$ と $r=2$ 近傍の例

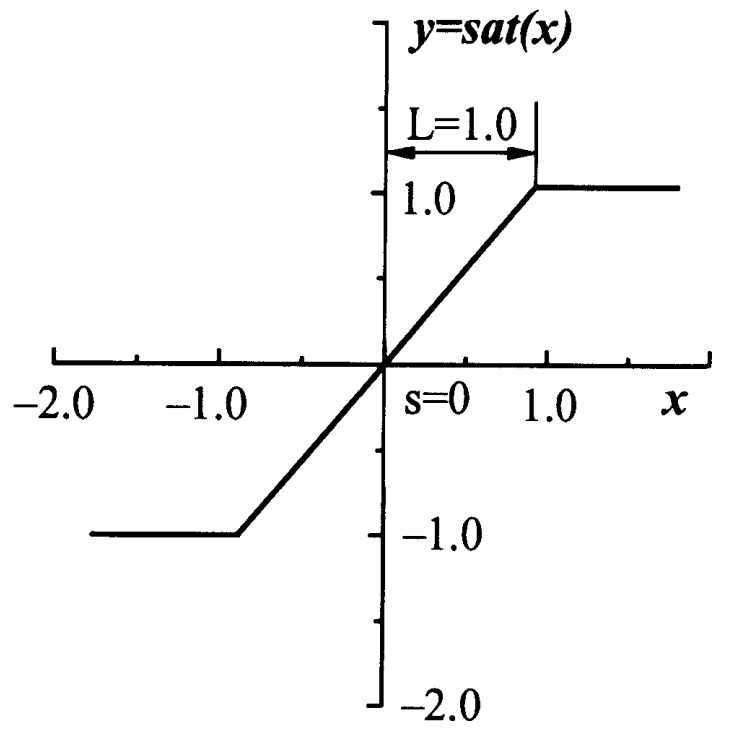

図 22 值出力関数の例

$$
\dot{\vec{x}}=-\vec{x}+T \vec{y}+\vec{I}
$$

となる，ただし， $\vec{x} は$ 状態べクトルで， $\vec{y}$ は出力べクト ルである. $T$ はテンプレート行列 $(N$ 列, $N$ 列)であり， Iは闌值ベクトルである。

成分が $+1,-1$ である $q$ 個のべクトル $\vec{\alpha}_{1}, \vec{\alpha}_{2}, \cdots, \vec{\alpha}_{q}$ が与えられたとき,CNN を構築するにはこれらを記憶 ベクトルとして持つ $T, \vec{I}$ を定めればよいことになる。 ここで, Liu \& Michel[11]の方法に従って次のように 仮定する。

$$
\vec{\beta}_{i}=K \vec{\alpha}_{i}
$$

ただし,パラメータ $K$ は平衡点の位置に関するパラ 
メータで, $K>L$, 出力関数の特性に左右されるもので ある.ベクトル $\vec{\beta}_{i}$ が式 (2)の平衡点での状態ベクトルで あるとすると， $\vec{\alpha}_{i}$ はその時の出力になる.この時, 式 (2)は次のようになる.

$$
\left.\begin{array}{l}
-\vec{\beta}_{1}+T \vec{\alpha}_{1}+\vec{I}=0 \\
-\vec{\beta}_{2}+T \vec{\alpha}_{2}+\vec{I}=0 \\
\cdots \\
-\vec{\beta}_{q}+T \vec{\alpha}_{q}+\vec{I}=0
\end{array}\right\}
$$

ここで, 行列 $G, Z$ を

$$
\left.\begin{array}{l}
G=\left(\vec{\alpha}_{1}-\vec{\alpha}_{q}, \vec{\alpha}_{2}-\vec{\alpha}_{q}, \cdots, \vec{\alpha}_{q-1}-\vec{\alpha}_{q}\right) \\
Z=\left(\vec{\beta}_{1}-\vec{\beta}_{q}, \vec{\beta}_{2}-\vec{\beta}_{q}, \cdots, \vec{\beta}_{q-1}-\vec{\beta}_{q}\right)
\end{array}\right\}
$$

とする.式(4)においてそれぞれの式と $\vec{\alpha}_{q}$ に関する最後 の式との差をとり,式(5)の行列表示を用いることによ り, 次式が得られる。

$$
\begin{aligned}
& Z=T G \\
& \vec{I}=\vec{\beta}_{q}-T \vec{\alpha}_{q}
\end{aligned}
$$

ここで，式(6)を満たすテンプレート行列 $T$ を求め るための煩雑で規模の大きな行列計算を避けるため,

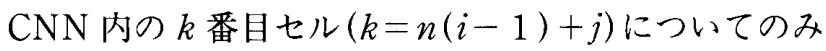
着目する，その満たすべき条件式 (6)は次式となる.

$$
\vec{z}_{k}=\vec{t}_{k} G
$$

ただし， $\vec{z}_{k}$ は行列 $Z$ の $k$ 行べクトルである. $\vec{t}_{k}$ は行列 の $T$ 行 $k$ ベクトル,すなわち $k$ セルにおけるテンプレ 一ト行列の各行要素と 0 要素を並べた行べクトルであ る.0要素以外の值を持つものは $r$-近傍,すなわち $r$ 個 離れた近傍セルまで接続しているものである。本研究 において, 簡単化のため, 近傍 $r$ の大きは個々のセ ルによらず一定值にした。 また，式（8）を満たすべク トル $\vec{t}_{k}$ の決定において，0 要素以外の値が重要である ので, $\vec{z}_{k}, \vec{t}_{k}$ およ゙ $G$ より $r$-近傍に属しない 0 要素を 除いた次の関係式 (9)を得る。

$$
\vec{z}_{k}^{r}=\vec{T}_{h}^{r} G^{r}
$$

ここで $G^{r}$ は行列 $G$ より $k$ 番目の七ルの近傍に属しない セルとの結合要素を取り除いたものである。また, $\vec{z}_{k}^{r}$, $\vec{t}_{k}^{r}$ は行べクトル $\vec{z}_{k}, \vec{t}_{k}$ より同様に $k$ 番目の七ルの $r$ 近 傍に属しないセルとの結合要素を取り除いたものであ る.式(9)において行列 $G^{r}$ は一般に正方形列ではないた め, $\vec{T}_{k}^{r}$ は特異值分解[12]を用いて次式のように与えら れる。

$$
\vec{t}_{k}^{r}=\vec{z}_{k}^{r} V_{k}[\lambda]^{-1 / 2} U_{k}^{T}
$$

ただし， $[\lambda]^{-1 / 2}$ は $\left[G^{r}\right]^{T} G^{r}$ の固有値の平方根からなる
対角行列の逆行列であり, $U_{k}, V_{k}$ は次式を満たす単位直 交行列である。

$$
G^{r}=U_{k}[\lambda]^{1 / 2} V_{k}^{T}
$$

この解は, 式 (9)の解の中でノルム最小のものであり, 偏りなく近傍のセルからの情報を与えられる。さらに, 式(7)に従って $\vec{I}$ も求められる。このように設計した $\mathrm{CNN}$ は, 理論的に記憶パターンがシステムの微分方程式系 の各平衡点に対応し, 初期パターンが与えられた際最 適な記憶パターンを想起する，すなわち微分方程式系 の最適解の安定平衡点に状態がとどまるようなネット ワークである。

\subsection{3 值出力関数およびその T-CNN の特性への影響}

2 值出力関数について, 出力関数 (図 2 参照)の非飽 和領域の大きさ $L$ に対して記憶パターンを想起するた めの時間 (以下, 完全想起時間, Complete Association Time, CAT)CAT が最小となる最適な $K$ が存在して いる。本研究では，シミュレーシュンにより 2 值出力

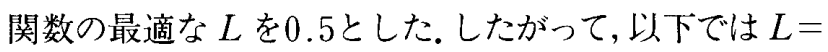
0.5 使用し， 3 值出力関数の設計を検討する.

ここで, 非飽和領域の大きさを $L=0.5 に$ 固定して非 飽和領域起点 $s$ を变えると, 四 3 に示すように, 例之 ば $s=0.1,0.3, \cdots$ などにより異なる 3 值出力関数 $y_{s}$ を 得ることができる，そして，成分が+1，0，一1である 図 4 に示すような $5 \times 5$ のマトリクス状における 5 個 のモデルパターンを記憶パターンにし，異なるパラメ 一タ $K$ を用いて2.1節で述べた方法により T-CNNを 構成する.図 5 に示すのはそれぞれ $s=0.1,0.3,0.5$, $0.7,0.9,1.00$ 場合の 3 值 $(-1,0,1)$ 出力関数を用いる $\mathrm{T}-\mathrm{CNN}$ のCAT と $K$ との関係の例である. 初期パ夕

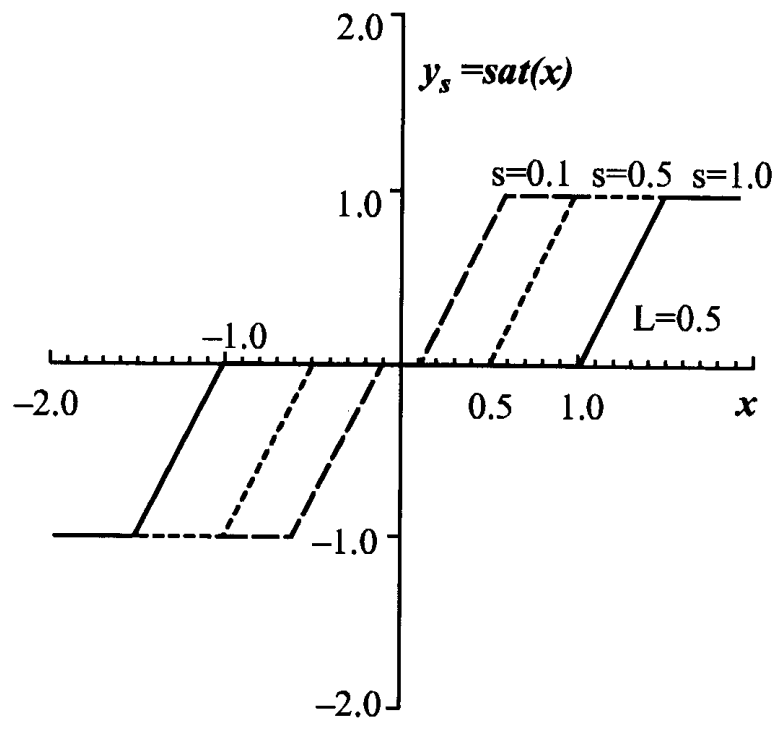

図 33 值出力関数の例 

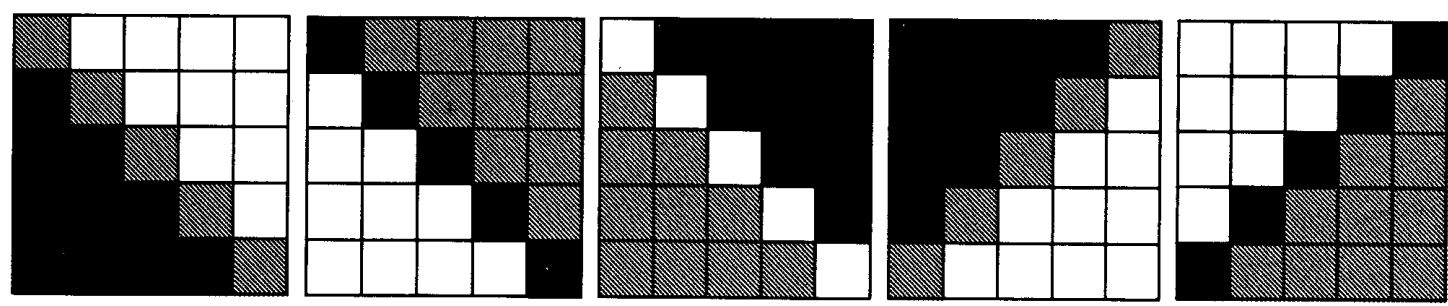

$-1$

$+1$

図 43 值 $(+1,0,-1)$ を有する $5 \times 5$ のモデルパターン

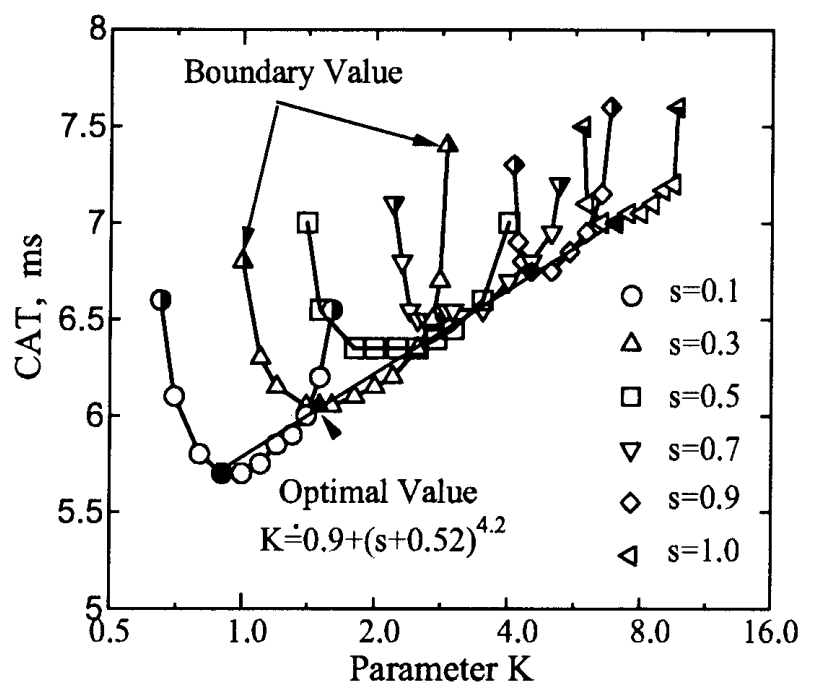

図 $5 \mathrm{~T}$-CNN の CAT と $K$ との関係の例

ーンは図 4 中の左から 1 番目のパ夕ーンに $\sigma=1.0$ のガ ウスノイズを加えたものを用いた．図 5 から分かるよ うに, 3 值出力関数を用いる $\mathrm{T}-\mathrm{CNN}$ はある $K$ の範囲 の中にしか平衡点に収束しない。例えば， $s=0.3$ の場 合において，Kの值は $K=0.9$ (左境界值)および $K=$ 3.0 (右境界值)を越えると T-CNN が収束しなくなる。 また, どの $s の$ 出力関数に対しても，CATがほぼ放物 線の形で $K$ の増加に伴って変化しており,最適な $K$ 值 が存在することがわかる。また，最適な $K$ は $s$ 值が 大きいほど大きくなり，近似的に

$$
K \doteq 0.9+(s+0.52)^{4.2}
$$

で表すことができる．他の初期パターンを用いる場合 もほぼ同様な結果が得られた。

ここで, 簡単でなおかつ有効な 3 值出力関数 $y_{s}=s a t$ $(x)$ の設計方法を提案する。すなわち

$$
\text { sat }(x)= \begin{cases}1, & s+0.5 \leq x \\ (x-s) / 0.5, & s<x<s+0.5 \\ 0, & |x|<s \\ (x+s) / 0.5, & -s-0.5<x<-s \\ -1, & x \leq-s-0.5\end{cases}
$$

ただし，各出力関数 $y_{s}=s a t(x)$ に対応する T-CNNの 設計パラメータ $K$ は式(12)により定める. 本研究では,
$\mathrm{CNN}$ の動作効率(CATの大きさ)を考虑し，図 5 より $s=0.3$ を選択した。そして， $s=0.3$ 有する 3 值出力

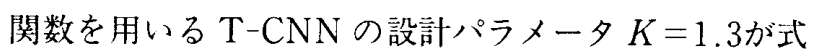
（12）により定如れている。

\section{T-CNNによる医療診断}

\subsection{T-CNNによる診断システムの構成}

計算機を用いた医療診断は本来医者による判定を, コンピュータにより自動的なおかつ正確的に与えよう とする試みである。しかし，その実現はかなり困難で ある。ここで，T-CNNを用いて計算機支援医療診断 システムを構成し, 病気の判定を試みる。川崎医科大 学から提供された肝臓の血液検查データ [13]は診断問 題のエッセンスをあまねく有していた特徴を持ち，診 断システムの性能評価によく適用されている[14]。し たがって, 本研究では提案手法の性能評価に肝臓の血 液検查デー夕を用いた。なお，T-CNN システムは， 2.2 節で提案した 3 值出力関数を用いる T-CNN であ り, 近傍 $r$ を 4 とした. 肝臓の血液検查デー夕はP1： Healthy（健康体）, P2：Acute Hepatitis（急性肝 炎), P3：Hepatoma (肝癌), P4：Chronic Hepatitis（慢性肝炎）および P5：Liver Cirrhosis（肝硬 変)の5種類のデータからなる。また，病気每には患者 50 人のデータがあり(合計 250 人)，各患者は $\gamma-G T P$ な ど20項目の血液検查結果が与えられている。このデー 夕の特徵は，ばらつきが大きく，たびたびデー夕の久 落, 異常値が存在している。

そこで，T-CNNによる診断システムの構成および 診断の手順を次のように提案する.

1. 血液検查の各項目を-1，0，1の3レベルに分け, 既 存の医学知識に基づいて図 6 に示した $4 \times 5$ の CNN にセットすると,P1：Healthy, P2：Acute Hepatitis, P3 : Hepatoma, P4: Chronic Hepatitisおよび P5：Liver Cirrhosisの典型的なパ ターンが得られる。

2. 第 2 章で述べた力法によりこれらの肝蔵病のパ夕 ーンを CNNの各平衡点に埋め込み, T-CNNによ る㟝断システムを構成する.

3. 表 1 に示すような患者の各血液検查項目の結果を 
表 1 血液検査結果とパターンの特徵量との関係

\begin{tabular}{|l|l|l|}
\hline$q_{k}:$ Characteristic parameters & $d_{k}:$ Iteams of blood test & Iteam's medicine names \\
\hline \hline$q_{1}=\left(d_{1}-15.0\right) / 12.0$ & $d_{1}:$ BUN & Blood Urea Nitrogen \\
\hline$q_{2}=d_{2} / 50.0-1.0$ & $d_{2}: \gamma$-GTP & $\gamma$-Glutamyl Transpeptidese \\
\hline$q_{3}=\log \left(d_{3} / 50.0\right)$ & $d_{3}:$ AFP & Alpha-1 Fetoprotein \\
\hline$q_{4}=\left(d_{4}-3.95\right) / 0.75$ & $d_{4}:$ Alb & Albumin \\
\hline$q_{5}=d_{5}$ & $d_{5}=0.0:$ & Nothing \\
\hline$q_{6}=\left(d_{6}-5.0\right) / 5.0$ & $d_{6}:$ UrA & Uric Acid \\
\hline$q_{7}=\left(d_{7}-90.0\right) / 60.0$ & $d_{7}:$ ALP & Alkaline Phosphates \\
\hline$q_{8}=q_{3}$ & $d_{3}:$ AFP & Alpha-1 Fetoprotein \\
\hline$q_{9}=\left(d_{9}-225.0\right) / 125.0$ & $d_{9}:$ ChE & Cholinesterase \\
\hline$q_{10}=\left(d_{10}-25.0\right) / 20.0$ & $d_{10}:$ PLt & Plate Let \\
\hline$q_{11}=\log \left(d_{11} / 50.0\right) / 0.5$ & $d_{11}:$ Tbil & Total Bilirubin \\
\hline$q_{12}=\log \left(d_{12} / 90.0\right)$ & $d_{12}:$ GPT & Glutamic Pyruvic Transaminase \\
\hline$q_{13}=\left(d_{13}-5.0\right) / 3.8$ & $d_{13}:$ II & Ic-Terus \\
\hline$q_{14}=0.0($ Lacking data $)$ & $d_{14}:$ LAP & Leucine Aminopeptidase \\
\hline$q_{15}=\left(d_{15}-45.0\right) / 30.0$ & $d_{15}:$ Dbil & Direct Bilirubin \\
\hline$q_{16}=\left(d_{16}-175.0\right) / 120.0$ & $d_{16}:$ LDH & Lactate Dehydrogenase \\
\hline$q_{17}=\log \left(d_{17} / 90.0\right)$ & $d_{17}:$ GOT & Glutamic Oxaloacetic Transaminase \\
\hline$q_{18}=q_{17} / q_{12}$ & $d_{18}:$ GOT/GPT & Ratio of GOT to GPT \\
\hline$q_{19}=q_{17} / q_{12}$ & $d_{19}:$ GOT $/$ GPT & Ratio of GOT to GPT \\
\hline$q_{20}=d_{20}$ & Nothing \\
\hline
\end{tabular}
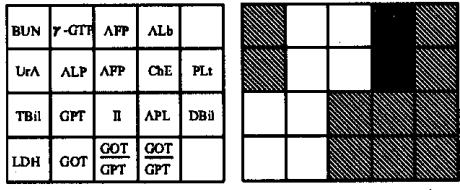

P1 Healthy Person
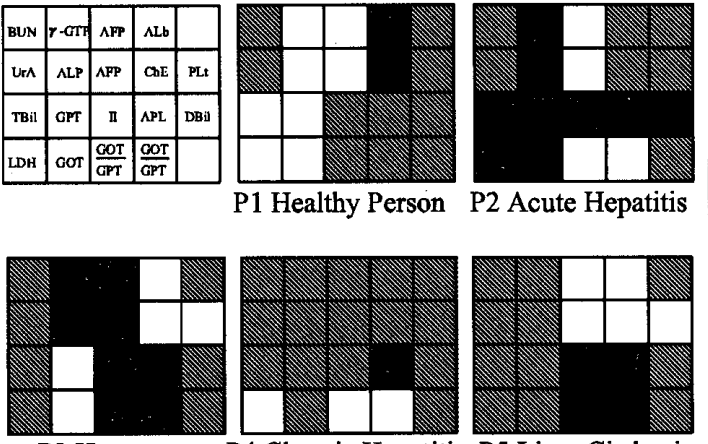

P3 Hepatoma P4 Chronic Hepatitis P5 Liver Cirrhosis

図 6 肝臓病パターンの例

$[-1,0,1]$ 上の数值に変換する関数を与える. 変換後のある患者のデー夕を $4 \times 5$ の初期パ夕一 ン(入力ベクトル)として使用する。ただし，表 1 に扔いて, $d_{k}$ は血液検査值, $q_{k}$ は変換後の初期パ夕 ーンの特徴量である。

4. 患者のデータから作成された初期パターンを T-

CNN に入力し連想させて得られた出力パターン(記 憶パターン)の病名を診断結果とする.

上述のように, CNN による診断システムはまず上述の 1.による病例から学習し，2，により学習した知識を システムに記憶させる。次に, 患者の特徴パターンが
与えられたとき, CNN が判定を行い記憶中のパターン と最も似ているものを思い出して判定結果を出力する. このような CNN の判定過程は, 医者が病例から学習し 知識を修得して，それに基づいて病気の診断を行う過 程とよく似ている。

\section{2 結果と討論}

表 2 に示すのは T-CNN による診断結果である. T $\mathrm{CNN}$ のパラメータ $K=1.3$ は $s=0.3$ 有する 3 值出 力関数に対応して式(12)により定めた．表 2 の行と例 の意味について，例之ば，P3行の No.列における数值 はP3：Hepatomaに属する患者の総数を表し，P3行 の P3列における数値はP3に属する患者が P3に正しく 判別される患者の数を表している。また，“Other”列 にある数值は $\mathrm{P} 1$ ～ 5 のいずれの想起結果ともならず， “その他”に判別された患者の数である．表 2 からわ かるように, P1：Healthy および P2：Acute Hepatitisの診断率 (Right Detection Ratio, RDR\%)が100\% に達し, P3：Hepatoma, P4：Chronic Hepatitis お よび P5： Liver Cirrhosis の平均診断率が70\%に達し た。また，病気がある患者が健康者に判定される例は 一人もいなかった。 
表 23 值 T-CNN による分類結果

\begin{tabular}{|l|c|c|c|c|c|c|c|c|}
\hline Liver diseases & No. & P1 & P2 & P3 & P4 & P5 & Other & RDR\% \\
\hline \hline P1 Health Person & 50 & 50 & & & & & 0 & $100 \%$ \\
\hline P2 Acute Hepatitis & 50 & & 50 & & & & 0 & $100 \%$ \\
\hline P3 Hepatoma & 50 & & & 35 & 1 & 1 & 13 & $70 \%$ \\
\hline P4 Chronic Hepatitis & 50 & & & 3 & 40 & 2 & 5 & $80 \%$ \\
\hline P5 Liver Cirrhosis & 50 & & 1 & & 4 & 30 & 15 & $60 \%$ \\
\hline
\end{tabular}

表 3 階層型 NN による分類結果

\begin{tabular}{|l|c|c|c|c|c|c|c|c|}
\hline Liver diseases & No. & P1 & P2 & P3 & P4 & P5 & Other & CDR\% \\
\hline \hline P1 Health Person & 50 & 50 & & & & & 0 & $100 \%$ \\
\hline P2 Acute Hepatitis & 50 & & 46 & & & & 4 & $92 \%$ \\
\hline P3 Hepatoma & 50 & & & 31 & 2 & 3 & 13 & $62 \%$ \\
\hline P4 Chronic Hepatitis & 50 & 1 & 2 & & 35 & 1 & 11 & $70 \%$ \\
\hline P5 Liver Cirrhosis & 50 & 1 & 1 & 2 & 6 & 26 & 14 & $52 \%$ \\
\hline
\end{tabular}

なお，同様のデー夕を使用し，統計的な手法を用い て診断を行った報告はまだ見られていないが，一部分 (病気毎に患者 20 人, 合計 100 人, 各患者の血液㭘查結 果が本研究と同じ20項目)のデータを使用し,ラフ集合 を用いたファジィ・if-then ルールによる診断の結果は 田中ら [14]により報告されている。診断結果の内訳は, P1：Healthy の診断率が100\%, P2：Acute Hepatitis が72\%, P3: Hepatoma, P4: Chronic Hepatitis および P5： Liver Cirrhosis の断率がそれぞれ59\%, $62 \% ， 65 \%$ である。ただし，健康体以外の肝臟病患者 80 人の内の 15 人が複数の病気に判定されて判定ができ なく, 診断率の計算には用いられていない。また, 慢 性肝炎および肝硬変の患者が各一人健康体に誤判定さ れている.データの取り扱いや判定率の計算に差巽が あるため一律な比較はできないが，提案手法の優位性 が確認できると考える。

さらに，図７（a）に示すような3層の階層型 NNを用 いて比較実験を行った。通常の階層型 NN の入力二ニ ットは $(0,1)$ のつの安定状態 ( 2 值) しかない.ここで $(-1,0,1) の 三 つ の$ 安定状態 ( 3 值)に対応できるように, 図 7 (b)に示すような入力ユニットペアを試みた。すな わち，入力層において，各入力ユニットの代わりに入 カユニットペアを用いる。すると，例之ば， $[-1,0,1]$ 上のある数值 $x_{k}=-1.0$ が与えられたときに，それに対 応して $k$ 番目のユニットペアは $x_{k}^{1}=0.0, x_{k}^{2}=1.0$ が得 られ， $x_{k}=1.0$ が与えられたときに， $x_{k}^{1}=1,0, x_{k}^{2}=0.0$ が得られる.この手法は $[-1,0,1]$ の領域を，0を中 心にした正と負の 2 領域に分け，各領域の範囲をそれ ぞれ $[0,1]$ に変換することに相当する.また，入力層 のユニットペアの数は図 6 に示した特徴量に対応する
ため20個とした，中間層のユニット数は試行錯誤の結 果40に設定し, 出力層のユニットは 5 個としてそれぞ れ 5 種類の肝臓病に対応する。学習は誤差逆伝播法を 用い，教師デー夕は図 6 に示した典型的なパターンの データを用いな。なお，学習は教師デー夕と出力值と の平均二乗誤差が 0.005 以下になるまで繰り返した。猃 断結果の判別について, 出力ユニットの出力值が 0.8 以 上であればそのユニットに対応する病名を診断結果と し, 出力值が0.8以下であればそれを不確寒な診断とし た。このようにして得られた結果，表 3 に示す。表 3 に示すように健康体が $100 \%$, 急性肝炎が $92 \%$, 肝臓が ン, 慢性肝炎および肝硬変の平均診断深が $61 \%$ であっ

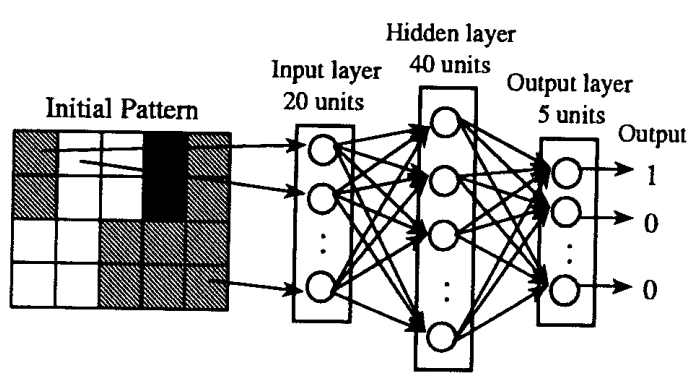

(a) Structure of the NN

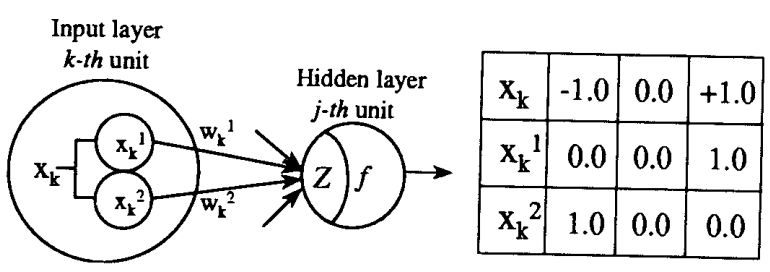

(b) Each input unit has a pair of units 図 73 層の階層型 $\mathrm{NN}$ の構成 
たままた，慢性肝炎と肝硬変の患者の内にそれぞれ一 人ずつが健康者として誤判別された。この結果により， 本論文で検討した肝臓病の診断において提案手法の優 位性が確認できた。

人間は，1)二つのパターンの類似性を判定するとき に，個々の項目だけではなくパターン全体の特徴で判 定することが多い，2)パターンの間に翼なる特徴点が 明確に存在すれば，一目で区別することができる，と いう特徵を持っている. CNNによる診断は, 従来の統 計判別手法の項目毎に判定結果に寄与することと異な り，すべての項目からなる患者の特徵パターンが判定 結果に笴与するという特徵を持っている。これは，人 間の特徵1)とよく似ている。ところが, CNN は, 特徵 パターンに寄与率の特に高い項目が存在する場合(例之 ば, AFP が高い場合, 肝癌の可能性が非常に高い), そ の項目が他の項目と一律に取り扱うため，その寄与率 が過小評価されるおそれがある。なお，CNNには各セ ルの項目設定を自由に行うことができる，通常 1 項目 を 1 セルに設定することに対して, 重要な項目を多数 のセルに重複に設定することができる，例えば，図 6 に示したパターンの項目設定において, AFPは肝臓が ンに対する高い寄与率を考虑して，2つの七ルに重複 して設定した。このようにして, CNN は人間に比較的 近い判定を行うシステムが実現でき，ほかの手法より パターンの全体の特徵を捆みやすく，専門家による総 合判断に近い判断が可能である.

なお, CNNにより判別できない患者については,や はり検查項目の欠落や異常値の存在などが多く, 病気 の特徵が不明確となって T-CNN による自己想起が記 憶パターンに収束することができなかった。今後，七 ルの項目セットの自由度を生かしながら, 問診のデー夕を併用して判定の精度を向上させることなどを今後 の研究課題としたい.

\section{4. おわりに}

以上， 3 值出力関数の設計を提案しそれを用いる 3 值の T-CNN を検討した。 そして，T-CNN を用いる 計算機支援医療診断システムを構成し，肝臟病を例に してT-CNNの判定能力を検討した。得られた主な結 果は次の通りである。

1. CNN について, 本論文で提案した 3 值出力関数の 設計方法を用いる場合, 出力関数に対応する最適 な 3 值セルラニューラルネットワーク T-CNN の 設計パラメータ $K$ を式(12)により定めることがで きる。

2. 肝臓病を例にして, T-CNNによる計算機支援医 療診断システムを試み，良好な結果が得られた。
その理由として CNN は人間に比較的近い判定を行 うシステムに実現され，パターンの全体の特徴を 搂みや寸く，専門家による総合判断に近い判断が 可能である。

\section{参 考 文 献}

[1] Zurada, J.M.: Introduction to Artifivial Neural Networks, West Publishing Company, New York. USA (1992) .

［2］中野馨監修：入聞と実習ニューロコンピュータ，技 術評論社 (1995) 。

［3］线野美代子：ニューラルネットワークを用いた層別因 子を含む回帰構造の解析, 計算機統計学. 14-2. pp. 123-138 (2001)

[4] 紙本伸明, 阿部敏郎, 林 鍵, 大松 繁：LVQ 法 によるインターホンの良否識別, 電気学会論文誌, 122C-4, pp.648-654(2002).

[ 5 ] Chua, L.O. and Yang L.: Cellular neural networks: Theory, IEEE Trans. Circuits \& Syst., CAS \} 35, pp.1257-1272 (1988).

[6] Chua, L.O. and Yang L.: Cellular neural networks: Application, IEEE Trans. Circuits \& Syst., CAS35, pp.1273-1290(1988).

［7］田中 衛, 斉藤利通：ニューラルネットワークと回路, コロナ社(1999)。

[8] Tetzlaff R.:Celular Neural Networks and their Applications, World Scientific (2002) .

［9］川畑洋昭, 章 忠, 金川明弘, 高橋浩光, 桑木宏： 特異值分解を用いたセルラニューラルネットワークに お汁る連想記憶に対して考察，電子情報通信学会論 文誌, J78-A-12, pp.1618-1626(1995).

[10］章 忠, 川烟洋昭：ホップフィールドネットワークと セルラーニューラルネットワークによる連想記憶につ いての比較検討, 計算機統計学, 9-2. pp.93103(1996).

[11] Liu, D. and Michel, A. N.: Cellular Neural Networks for Associative Memories, IEEE Trans. Circuits \& Syst., CAS-40, pp.119-121(1993) .

[12] Strang, G.: Linear Algebra and its Applications, Academic Press, Inc. NewYork（1976），山口昌哉 監訳： 線形代数とその応用, 産業図書(1994).

[13] 日本ファジィ学会編：ファジィ OR, 日刊工業新聞社 (1993).

［14］柳井晴夫，岡太彬詶，繁桝算男，高木廣文，岩崎 学：多变量解析実例ハンドブック, 朝倉書店 (2003).

(2003年 9 月 5 日 受付)

(2004年 3 月21日 採録)

[連絡先]

于701-1296 岡山市芳賀5301番地

岡山噁工業技術センターシステム技術部

章 忠

Tel : 086-286-9620

Fax : 086-286-9632

E-mail : zhang@okakogi.go.jp 


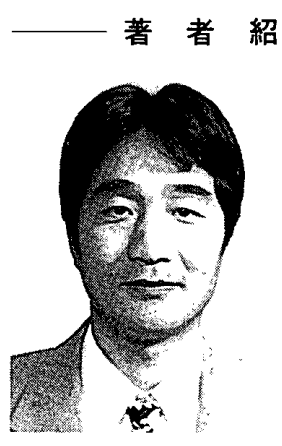

\section{介 章 ${ }^{2}$ 忠}

岡山监工業技術センター

1984年中国西安公路学院修士課程修了。 1993年岡山大学大学院博士後期課程修 了. 剛山県立大学情報工学部 教務職員を 経て, 現在, 岡山県工業技術センター尃 門研究員, 岡山県立大学連携大学院助教 授兼務。博士(工学)。1998年～99年メル ボルン大学客員研究員、ウェーブレット 解析による信号・画像処理, ニューラル ネットワークの研究等に従事。日本機械 学全, 計测自動制御学会, 自動車技術会 等の正会員。

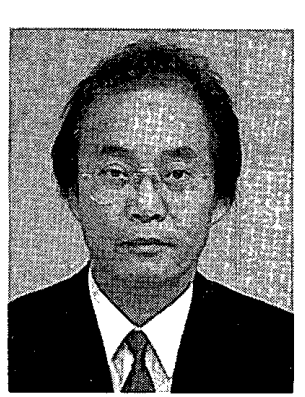

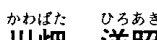

川烟洋昭 [州会记

岡山殞立大学情報工学部情報システム 学科

1967年大阪府立大学卫学部電気工学科卒 業．问年松下精工（株）入社。1969年大 阪府立大学工学部電気工学科助手, 1993 同講師, 1994年岡山罧立大学情報工学部 情報通信工学科助教授, 1997年同情報シ ステム工学科教授。現在に至る。工学博 士. 非線形システムにおける振動の解析 および制御ニューラルネットの応用に関 する研究に従事, 電子情報通信学, 計測 自動制御学会, システム制御情報学:会等 の正会員。

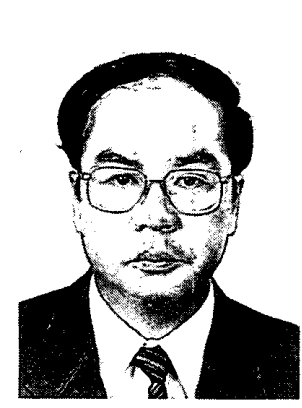

金川 明弘

岡山県让大学情報下:学部情報通信一学科 1983年神戸大学工学部システム工学科卒 業. 1989年大阪府立大学厂.学部経黨工学: 科助手，1993年岡山県证大学情報、学部 情報通信工学科助教授。現在に至る。博 士(工学)．情報量䋨計学の管理技術への 応用, ニューラルネットワークの組合せ 最適化問題への適用等の研究に従李。電 子情報通信学会, 情報処理学:会, システ

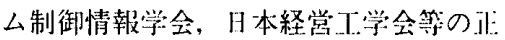
会員

\title{
Associative Memory using Cellular Neural Networks and its Application to Medical Diagnosis
}

\author{
by
}

\section{Zhong Zhang, Akihiro Kanagawa and Hiroaki Kawabata}

Abstract :

It is very difficult to realize medical diagnosis systems on a computer, because in order to judge many sick support groups synthetically, generally one needs to use the data that consists of dozens or more items (the amount of the features). In this paper, a computer-aided medical diagnostic system is constructed using the Three-valued Cellular Neural Network ( $\mathrm{T}-\mathrm{CNN})$, which has achieved excellent results in pattern classification, and the classification capability is examined by using liver disease data as an example. Consequently, a comparatively good diagnostic result is obtained from the T-CNN under the conditions examined by this study. Because the T-CNN can realize a system which performs the judging comparatively near humans, and tends to utilize the features of the whole sickness pattern, it was concluded that it could perform judgment nearest to the overall judgment by a specialist.

Keyword: Classfication Problem, Detection, Liver Diseases, Cellular Neural Networks

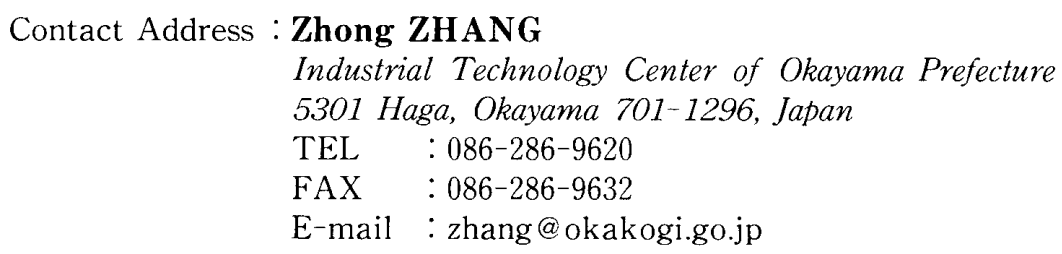

